\title{
What medical students learn about death and dying
}

\begin{abstract}
Death and dying remain taboo in modern societies. Care at the end-of-life is limited, even in advanced countries with an efficient public health system like Spain. In this paper I demonstrate that the knowledge acquired by the medical students in the textbooks they use during their studies in the medical school about end-of-life care and better dying is minimal. The majority of those textbooks is in English, and/or published by international publishing houses. I analyze both, national and international textbooks, as far as they are actually included in the reading lists of the 44 courses of the six years of the Medical School at the University of Barcelona (Spain). I work with 2,868 textbooks used by the students and recommended by teachers. I analyze all those books classified as textbooks at the library of the Medical School and Hospital Clínico (teaching hospital funded in 1906) in the heart of Barcelona. It is the best medical school and the best medical library in the region. I review the textbooks by courses and medical specialties. Some of those courses - like public health, and medical psychology- do not deal adequately with the care at the end-of-life. The transitions to death of terminal patients are absent. I only found relevant information in some textbooks (like oncology, family and community Medicine). But even in those cases the information is biased and not original. The terminal patient care -i.e. the transition to a better dying- is neglected in the medical schools. A modern model of death (MMD) is still absent in the medical textbooks researched. The case of Spain is probably similar to other countries, as it uses practically the same textbooks, but that needs to be demonstrated using further data.
\end{abstract}

Keywords: medical sociology, death, better dying, end-of-life, medical students, terminal patients, palliative care, education, university textbooks, medical school.
Volume 4 Issue I - 2020

\author{
Jesús M De Miguel \\ Professor of Sociology, University of Barcelona, Spain \\ Correspondence: Jesús M De Miguel, London School \\ of Economics, PhD Yale University, Professor of Sociology, \\ University of Barcelona, Spain, Tel +34 630050 850, \\ Email jesusdemigel@ub.edu
}

Received: December 16, 2019 | Published: January 16, 2020
"La mayor locura que puede hacer un hombre en esta vida

es dejarse morir, sin más ni más, sin que nadie le mate,

ni otras manos le acaben que las de la melancolía".

Sancho Panza. ${ }^{*}$

\section{Multiple concepts}

To write about death kills. Doing research about death and dying kills even more. But death allows us to understand life. Death even structures society. ${ }^{1,2}$ Metaphorically death is also a birth. But "to killthe-father" is not always a simple metaphor. Other people believe in near-death experiences, out-of-body events, and religious epiphanies. ${ }^{3}$ Here, in this paper, I am not going to define death or dying. These are expressions that seem obvious for the population. Everybody knows to what I am referring here by "the end-of-life": just the last few days of life. But how many? It is difficult to be concrete as each patient and illness are different. I am undertaking a study on Spain. The dictionary of the Real Academia Española, mentions that death (muerte) is the separation of body and soul. Many people believe in the existence of the soul. The soul is a great invention. But if we look at alma (soul) in the dictionary then we are lost. Death is also one of the four horses of the Apocalypses, precisely the yellow horse. The population distinguishes between a good death and a bad death. In Spain the good death is a Christian one, and usually "con las botas puestas" (while

$1^{*}$ "The biggest madness that a person can make in this life is letting himself die, simply, without nobody killing him, no other hands finishing him but those of melancholia." Sancho Panza at the very end of the second volume of Don Quixote. It refers to the fact of "to live crazy and to die sane" "vivir loco y morir cuerdo") as it appears in the final chapter 51, referring to Don Quixote. still working). The end-of-life in Spain is then a strange combination of religious connotations and some macho attitudes; Vovelle, Michel $^{4}$ but it is not so in the textbooks where the students learn Medicine. The medical textbooks - many of them in English- hardly mention the end-of-life, less so about how to take care of it, and never about the afterlife. But we all need to allow for the complex mixture of the modernity of the technological Medicine, and the baroque rituals of traditional funerals. In contemporary society there are few examples of that extreme combination of tradition and modernity. ${ }^{2}$

Medical textbooks tend to incorporate new concepts, like "natural death" without providing a clear definition of it. The books also talk about "terminal patients", and "dying patients" without a definition. It is also the case of "sudden death", and of "clinical death". Expressions used widely like "agony" are also unclear. A patient with an "incurable illness" is a complex notion. And illness can be terminal, but textbooks also refer to "terminal patients". "Fatal prognosis" is a much more educated term for the end-of-life. "Fatal" is an expression widely used in English, but it has a different meaning in Spanish (colloquially bad, badness).

${ }^{2}$ This paper was inspired by an excellent medical doctor (Manuel Borrell Muñoz) and his brave daughter, a medical student (María Borrell). Thanks also to Dr. Esteban Poch, and Adriana Vives, in the clinical trial, at the Hospital Clínico of Barcelona, and to Nuria Salazar in physiotherapy. My life is in their hands - not metaphorically. Papers about death are difficult to complete. In the sociological profession we say that "they kill" the authors. And it is true. I overcame that bad spell by working at the same time on an empirical study on happiness and satisfaction with life; just published: Julio Iglesias de Ussel, and Rebeca de Juan, eds. La felicidad de los españoles. ${ }^{9}$ Julio and his family are the best medicine for happiness. But a closer support came from my wonderful wife Ching T. Liao. I wrote this paper in spite of our three-years-old son Max. 
Death is a taboo, as it is discussed in scientific literature: for example by Zygmunt Bauman ${ }^{1}$ in Europe or by Terrence Holt ${ }^{5}$ in the United States. The process of dying is mainly hidden or even made invisible. But what is interesting in the present paper is that this taboo includes the students of Medicine. The end-of-life has been taken by institutions: hospitals, palliative care units, hospices, funeral homes, and cemeteries. There is also the big business of death, described brilliantly by Jessica Mitford in her classical book The American Way of Death ( ). ${ }^{6}$ So the medical school uses other obscure concepts like "complex chronic patient" (in Spanish PCC) and "palliative needs" (in Spanish Necpal). Sometimes medical doctors (and students of Medicine) use some terminology to alert other professionals, such as: "difficult patient" or "problematic patient". There are some debates -even workshops-about "how to break the bad news".

I acknowledge that death concepts are potent, but vague, symbolic, often with multiple meanings. That is typical of taboo subjects. Before analyzing the medical textbooks in the library, for their content about the end-of-life care, I have three initial tasks. The first task is differentiating death from dying: muerte from the process of morir. In Spanish is even unclear than in English. There is a complex difference between morir and morirse: like morir from cancer, and morirse from cancer. The difference is simpler between matar y matarse: kill somebody and kill oneself. The second task is to differentiate the personal experience of the end-of-life, from the end-of-life of others. The dying process of other people -especially family and friends- is usually the best socialization process about the personal experience of dying. People learn about death and dying through viewing and experiencing the death of relatives, and through observation/ participation. However, this socialization and learning process should be different in the case of medical students. A more scientific and systematic knowledge is expected to be learned at the medical school. The third task is to differentiate between "physical death" and "social death". In sociology social death occurs when it is made public that a person has a terminal disease or is actually dying. It increases her isolation and solitude. Social death occurs before real death, making the end-of-life process more painful.

I observed that other topics related to the end-of-life -such as morbidity and mortality- are also diffused and vague in the medical textbooks. It is the case of suicide, medically assisted suicide, euthanasia, and autopsy. Nothing is being said about the afterlife. Medical textbooks -even in Spain- do not believe in soul or in spirits. There is no discussion about a second life, life after this life, or afterlife. I agree that those topics should not be discussed in scientific books. The obituaries (in the newspapers, for example) they sometimes refer to death as the "last hours", and also "to give the spirit". The textbooks nothing say about the popular problems of the end-o-life: the preparation of the dead body, wake, funeral, cemetery ceremonies, the use of black clothing, coping with grief, and so on. The taboo of death reaches also social research. From a philosophical perspective I recommend Death and the Afterlife by Samuel Scheffler. ${ }^{7}$ But the most influential study is Elisabeth Kübler-Ross, ${ }^{8}$ On Death and Dying: What the Dying Have to Teach Doctors, Nurses, Clergy and Their Own Families $\left(1969,2009\right.$ is the " $40^{\text {th }}$ anniversary edition of the book", after the death of the author in 2004). This book - and authorhas an enormous influence; even the ending practices of the author were widely criticized.

\section{Medical studies and textbooks}

Medical textbooks here refer to the six years of studies for the MD degree (grado) in the case of Spain, and concretely in the School of
Medicine of the University of Barcelona. Each course is allowed to recommend up to 10 books as readings to be included in the library. The study structure is rigid; compulsory courses are $95 \%$ of the total credits (360 credits). The distribution of compulsory courses can be seen in Table 1. Courses are organized in six academic years. There are two terms per year, with no classes in the summer. In this table I do not differentiate by terms. The first three years are called "preclinical years". The students have courses of natural sciences, sociodemographic causes of illness, and body systems. They also include the different natural sciences. The last three years $\left(4^{\text {th }}, 5^{\text {th }}\right.$, and $\left.6^{\text {th }}\right)$ are called "clinical years". They include the different medical specialties, and strategies of curing. They are organized mainly by human organs. The order is not totally clear: blood at the beginning, pediatrics at the end. In the sixth year there are some (limited) practical work at the hospital, and also of general medicine. There is also a final work, or paper, that is not very important (only 6 credits from a total of 360 credits). The distribution of courses is quite compulsory. Students do not take big decisions about what to study or when. The study plan is rigid, and has been decided for them. There are some decisions that seem illogical: like public health and statistics in the $5^{\text {th }}$ year. The other characteristic is that this organization of courses is international. Courses taken are very similar to the ones taken in other countries. Students use the same international textbooks (in English) in many of the courses. Textbooks in the medical studies are exhaustive; most textbooks are around one thousand pages; and some textbooks are even longer.

Notes: This is the official curriculum for the MD degree at the University of Barcelona, Spain. The number of medical courses for the MD degree — called "grado"- is 360 credits (or ECTS), in six years, around 30 credits per term (two terms each year; there are no classes during the summer). These courses are compulsory; there are only $5 \%$ of courses than are optional. It is then a degree with very little optional courses. There is a final paper for the degree that is compulsory (but only 6 credits) less than $2 \%$ of total credits. Here the courses are ordered by alphabetical order within each year, not differentiating them by term. I expect that the courses with a (*) have more information about the end-of-life, terminal patients, assisted suicide, death, and dying. Introduction to health is taught by faculty from the Department of History of Medicine.

Medical textbooks tend to be one thousand pages long. There are textbooks with more than 2,500 pages. Many authors, usually professors or teachers of that course, write chapters in those long textbooks. There are solid textbooks, both in Spanish and in English. Many times the Spanish edition is just a translation of the textbook published originally in English. I should state here a general reflection: American textbooks (produced by top United States medical schools) tend to be the state-of-the-art in the world. That means that are long textbooks (usually longer than 2,000 pages), very serious and empirical, research oriented, that define all the topics that should be included in that course. So they define "the cannon" of each specialty. Later, some Spanish local textbooks try to match that wide scope, with more limitations. Textbooks can be published for other purposes, like the prestige of a medical school (with a hospital) or the symbolic power of a catedrático in Spain. Textbooks like the Nelson, with 3,500 full pages, for pediatrics, in its $20^{\text {th }}$ edition, cannot be one of the courses to be fully studied by the medical students in (one term of 4 months of) their sixth year. It is more a reference manual, or, as I said, a symbol of prestige for the editor, authors, and editorial press. The Nelson is then a reference benchmark for the medical learning about pediatrics, in the whole world. 
Most textbooks reflect exactly the name of the course. Sometimes the name of the course changes and so it does the title of the textbook. For example, in public health the most widely used textbook is called "El Piédrola" (by the name of the oldest professor in the area). Between 1962 and 2008 it had eleven editions. First, it was called Lessons of Hygiene and Health. Two years later the title changed to Social and Public Medicine: Hygiene and Environmental Health. In 1988 the same book changed to Preventive Medicine and Public Health. It is now a thick volume of 1,390 pages, which explicitly includes chapters by all the full professors that are teaching that course in the Spanish (public) universities. The book explicitly states that the professors, when they retire (in Spain it is compulsory by 70 years old), they leave the textbook, allowing new chapters for "the new generations of professors of that course". ${ }^{10}$ The textbook needs a high level of coordination, and it is probably a good business. In page iv the book prints: "To photocopy is a crime". However, this textbook is quite conservative and old fashioned. The book does not say anything about death and dying, or the care towards the end-of-life. It simply affirms, "Deaths in Spain are mainly of aged persons" (sic page 997). In the textbooks mentioning the end-of-life usually discuss it at the end of the textbook; often in the last chapter.

During the time of my research in the Medical Library -in the last two years- I observed that most students were not reading books from the library. Students study hard on photocopied books (with a metal spiral in the spine) and at the computer. It is not clear if those were photocopies of textbooks and recommended readings. They looked more like a summary done by someone; perhaps former students made accessible the notes on the internet; but not the students' notes. They looked at the computer mainly for images (in color) while at the same time studying from the notebooks. Other students were preparing the MIR (intern and resident medical doctors) examination. They also used photocopies. Students do not carry books, and do not consult books in the library. But they can borrow books. From the essential textbooks there are always several copies. So the library, usually full, it is more a reading room than a library resource. There are four reading rooms $-\mathrm{A}, \mathrm{B}$ and $\mathrm{C}-$ plus the room of computers. In each cohort there are 260 students. That makes a global number of around 1,500 students in the medical school.

For each course about 260 students is a very small number to make profitable a textbook of more than one thousand, or even two thousand, pages. So the textbooks tend to be a collaboration of different medical schools. Or they are special and significant efforts to show the state-of-the-art in one specialty. That is, a medical school (Harvard, Complutense, Barcelona) and the adjunct hospital (MGH, La Paz, o Clínico) make the work of writing to show others how much they know about a medical specialty, how modern (in ideas and technology) they are, and what should be the ideal scope of each course/textbook.

\section{Data and hypotheses}

The library of the Medical School of the University of Barcelona, in Spain, together with the University Hospital (Hospital Clínico) at the center of the city, Casanova Street 143 - has about $4 \%$ of the total books of the University, which are 1.3 million volumes. It is the second largest university library in Spain (after Universidad Complutense, in Madrid). So the total volumes of Medicine are around 50,000 books. The exact number is difficult to know. The School of Medicine, and so the library includes four different basic careers (with a bachelors BA degree called grado): Medicine, Nursing, Biomedical engineering, and Biomedical sciences. Medicine is the central one. From them, the books officially catalogued as textbook for students are 2,868 books, or $6 \%$ of he total Medical library. The sample I used for this research is the total, which means that I have revised the 2,868 books. Those are the recommended textbooks that the students may use for the preparation of the 44 different courses. Each Department at the Medical School can select up to 10 books for each course they are teaching. Each academic year these books change. Until 3 years ago (when I began the research) these books where separated in a special "Library of the Student". But not anymore. Now textbooks are mixed with all classes of medical books, but keeping a special green band in the spine. That allows for more space for students in the library, and that the students have other books - not only the recommended onesto study. The library assign the greed band to the last three editions of each recommended book. And textbooks in the Medical School usually have many editions. Textbooks are in Spanish and English. At the time I am doing this research there is a big debate about the independence of Catalonia (Barcelona is the capital). However, it is interesting to notice that in the reading lists of the 44 courses of the Medical School there are no textbooks in Catalan. ${ }^{3}$ There are all in Spanish or in English.

The organization of the library, in the Medical School ( $7^{\text {th }}$ floor), follows the international signature system. But within the medical subjects there is not a big section on death, dying, or end-of-life. Less so on afterlife. There is a small section on geriatrics, or gerontology, and another one on palliative care. ${ }^{4}$ But there is an optional course in gerontology. The references to death in all manuals are marginal. Sometimes there are references at the very end of books of some specialties; sometimes a paragraph about "terminal patients" in that medical area. There is not a coherent explanation, in the textbooks, about the process of dying. References are very scattered. So it is difficult to analyze, but it is important to do it. There are two additional problems. Firstly, perhaps the students of Medicine learn about death and dying in other books but not in medical textbooks. I do not think that is the case. Secondly, more probable is that young medical doctors (or interns) learn about the death of patients through mouth-to-mouth communication, or by attending hospitalized patients. Unfortunately I cannot include the analysis of these two processes in the present paper. However, I plan to do some future research. The reference of all books used here, and which say something about the end-of-life, are included in the bibliography at the end of the present paper, citing the reference numbers of the library. So, I allow other researchers to question this paper, or to replicate it in the future. To find the books in the stacks I include the distribution in the $\mathbf{q}$ (at the end of the present paper).

The main hypothesis 1 is that there is very little information about the end-of-life in the textbooks of the 44 courses of the Medical School. That is quickly explained by referring to the idea of the death taboo, which includes even medical students. The hypothesis 2 is that there are no discussion about end-of-life processes in the textbooks that you would expect most treating this topic, such as epidemiology, demography, psychology, ethics, psychiatry, toxicology, and public health. It is more a topic discussed in the specializations related to

\footnotetext{
${ }^{3}$ This is not entirely true. One of the recommended readings is a History of Medicine in Catalan, by Josep M. Calbet and Manuel M. Escudé11 with a strong pro-Catalan bias.

${ }^{4}$ The big sections that are closer to the topic of the present paper appear in the
} Annex, at the end. 
fatal illnesses like cancer (so in oncology). Also in family Medicine. Hypothesis 3 is that cases in which a discussion about terminal patients and their families is expected, the content tend to be copied from other international books, not being original. The modern model of death (MMD) is not developed in these medical textbooks. Hypothesis 4 is that in cases in which the textbook (of that specialization) discuses death or dying, there is little discussion on the care of terminal patients related to the end-of-life. Hypothesis 5 is that Spanish textbooks ignore more the end-of-life processes. Foreign textbook, in English or translated into Spanish, tend to include more information about the end-of-life. So I always mention if the author is foreign or Spanish.

I analyze the discourse presenting topics of death and dying of patients, in the rare occasions they appear. Specifically I am looking for several characteristic of the discourse on death and dying, and the care of terminal patients:

1. How authoritarian is the relationship of the physicians (or nurse) with the patient. The physicians give orders, and the patient should assume a passive obedient role, with an explicit desire to be cured. It is the patient role described by Talcott Parsons in chapter 10 of the Social System. There is no teaching about a model of active patient taking decisions, helped by the technical expertise of the physicians, and keeping control over her own illness.

2. The textbooks say little about care. Sometime they define the problems of the end-of-life, but the textbooks do not assume how to take care of those terminal patients. Textbooks do not define well what a "good death" is.

3. It is accepted that the role of the family is important, but those texts present the family with high levels of control over the patient. Some international textbooks mention the "conspiracy of silence" and how to overcome it.

4. Implicitly all textbook consider that the topic of end-of-life belong to another field or textbook. No areas of knowledge take charge fully of this topic. The exception is palliative care books, but there is no one in the compulsory readings for the medical students.

5. References about dying and death are located at the end of the textbook, like something that is marginal o the core of the textbook.

Having 44 courses in the Medical career it is possible for each course/textbook to think that there is another course that treats the topic of death and dying. As they can suggest only up to 10 textbooks per course, each Department thinks that the end-of-life correspond to another Department. It is a consequence too of the "taboo of death". That way no text in the medical career really studies the end-of-life process. Only by showing them - the Medical School authorities and faculty- that nobody is developing the end-of-life care they will, perhaps, change the curriculum (or the textbooks). The faculty should take seriously the MMD (modern model of death) and develop it in some textbooks. That way the medical curriculum will be much better. It is necessary a global evaluation of the medical textbooks, and so of the medical learning process which is changing in the whole world.

Evaluating the discourse analysis we need to take into account that the heath system in Spain is mainly public, and that the relationship physician/patient occurs mainly within a public space and institution.
There is a minority private health sector, but students in the Medical School are taught mainly with the idea that they will be professionals working in the public system. However, later on, many students do not follow that work pattern.

\section{End-of-life in the basic courses}

Each course has up to 10 textbooks recommended. Textbook in English, mainly produced in the United States, are usually thick books (volumes about one thousand pages, and sometimes between 1,000 and 2,000). They cover a wide variety of topics, with suitable texts. I think that those texts are really defining the extension of each course or specialty. Spanish manuals are marginal, and some of them are even "peculiar". The importance of textbooks are so clear, that many are known by the name of the original editor (often already dead), like in Spain Botella, Cruz, Piédrola, Laín-Entralgo, or Surós. Internationally examples are Casarett \& Doull, DeVita, Hazzard, Ellenhorn, Goldfrank, Hellman and Rosenberg, Holland-Frei, Knight, Nelson, Tintinalli's and so on.

Introduction to health: There is nothing about death and dying. I expected much more of the manual written by the Spanish psychologist Ramón Bayés, Aprender a investigar, aprender a cuidar (2012) but the book does not really develop any concrete ideas about death and dying, less so about care at the end-of-life. It includes a list of films about death (pp. 215-216) including The Seventh Seal (by Ingmar Bergman, 1957), but little more.

Epidemiology: It is a modern specialty. However, the five different manuals of epidemiology I found in the sample they say nothing about the end-of-life. Only A Dictionary of Epidemiology, well edited by professor Miquel Porta ${ }^{12}$ and by Oxford University Press, includes brief definitions of "death rate", "death registration area", "mortality statistics" and "mortality rate".

Introduction to research: The Department of Medical History mainly teaches this course. There are several good textbooks, like Laín Entralgo, and López Piñero. But there are no contents about death and dying. The History of Medicine of professor Pedro Laín Entralgo $^{13}$ is already a classic. For him (Laín) "illness is a form of living" humanly (p. 626).

Psychology: For Psychology, applied to Medicine, the students use several books. The surprise is that most of them say nothing about death and dying. That is the case of the recent textbook of professor Isaac Amigo Vázquez, Manual de psicología de la salud. ${ }^{14}$ In Psychology they also use the textbook of David G. Myers, Psicología ${ }^{16}$ originally in English, but already with seven editions in Spanish. It is a long textbook (741 pp.) but the topic of death is dealt with in only two pages (pp. 186-187). It maintain an optimistic tone but very general: "Even death is almost never welcomed, life can be affirmed also in the moment of death. That happens mainly in the cases of those persons that make a revision of their life not with sadness but with what [Erik] Erikson called the feeling o integrity, that is a feelings that life has had a meaning and that it was worthwhile to live" (p. 187). How do you teach students into producing that feeling in their future patients? There is an English textbook (this time by Myers and Dewall ${ }^{17}$ ) that students also use. It has a small section on "Death and dying" (only one page: 225) which begins this way: "Warning: If you begin reading the next paragraph, you will die". The section concentrates only on grief. Quite a surprise that such a big -and complete- textbook says so little about death. 
Another textbook - this one in English- is Olle Jane Z. Sahler and John E. Carr, titled The Behavioral Sciences and Health Care (2007 in the second revised edition). ${ }^{18}$ It says very little about death and dying. Within "Psychiatric Disorders" (sic) it includes a few ideas about assisted suicide. Then in "Hospice care" mention what it calls "death with dignity". This textbook tells the students not to agree with assisted suicide, but to better accept the interruption of artificial feeding. It makes sure the readers that it is demonstrated that patients do not suffer from that interruption. Without feeding patients die in one or two weeks. According to the book, it is a quiet death, which the textbook compares with the natural death in the past, before contemporary Medicine (p. 263). In terminal patients this manual is in favor of stopping artificial feeding, and also stopping feeding through the mouth. But the textbook insists that this is not PAS (physician-assisted suicide), which would include giving the patient a substance or medication in order to produce death. The book adds that this one is also a death without suffering. The book is then ambiguous about PAS. It mentions progressive policies in the State of Oregon (in United States), and in The Netherlands. But it does not have a clear position about PAS. It prefers to allow the patient to die from hunger. At least that is what medical students learn from this textbook. The third edition does not change that position. But at least it affirms that "Medicine cannot prevent death, but it can make death less frightening by giving patients control over its manner and timing" (p. 279). The books present death always from the point of view of the medical doctor.

The most interesting textbook is Shelley E. Taylor, translated from American English, Psicología de la salud,$^{19}$ already in its $6^{\text {th }}$ edition. Chapter 12 is specifically about "Psychological aspects of advanced and terminal sickness" (pp. 315-340). It connects death with pain. "What patient are more afraid of is not being able to control pain; they can even welcome or look for death in order to avoid pain" ( $p$. 330). The book discusses the model of five stages of dying by KüblerRoss $^{8}$ (in pp. 328-330). In Spanish they are: negación, enojo, tristeza, depresión, and aceptación. There are problems of translation because the third stage should be "bargaining" and not "sadness". It informs the readers that all these five stages do not always occur, and that in some patients they happen in a different order. But the book does not include other more profound criticisms about the Kübler-Ross model; such as the third stage is usually a bargaining with God. The model is basically functionalist: the most important at the end is to accept your own death. And so also the acceptance of the institutions that manage death. It is a model that is too conformist and possibly not very real. "Because is a taboo topic, many people have mistaken conceptions, including the idea that the person dying wants to be alone, and not to talk about the situation" (p. 338). At least this medical manual is favorable to an education towards death.

The library includes a section on "Semiología" which refers to Diagnosis and examination. The medical students use specially the textbook edited in United States by Mark H Swartz. ${ }^{18}$ In English the original book is titled Textbook of Physical Diagnosis: History and Examination. It is translated into Spanish as Tratado de semiología: Anamnesis y exploración - to be adapted to the course in the third year of the medical school. It is interesting to notice how Textbook in English is translated as Tratado in Spanish, in this case and in many others. Chapter 22 is about "The geriatric patient". See also chapter 27 "Caring for patients in a culturally diverse society". But this chapter is not in print, in the book, but available only on the Student Consult site. Spanish textbooks (like Surós and Durós,$^{20} 8^{\text {th }}$ edition in 2006) do not include discussions like that; nothing on end-of-life care. ${ }^{5}$

Medical ethics: It is not even a course in the third year of medical studies, but the last part of a course on diagnosis (anamnesis and exploration) and clinical propedeutics. The relationship is unclear. An idea of the content of the Spanish textbooks on ethics is the one of professor Diego Gracia, ${ }^{21}$ Fundamentos de bioética $\left(3^{\text {rd }}\right.$ edition in 2008 , with 605 pp.). It is also an example of a characteristic of medical education in Spain: the local authors, especially full professors, and the ones in charge of a course in a medical school, they can say and write whatever they want. All the students have to study that textbook, with no real possibilities of criticizing the content. That example of authoritarian teaching happens even when the textbook is simply impossible to read or to understand. As a short example of what I am saying read the last pages of this book on "The perfect physician" (pp. 597-602). Unknown publishing houses, usually a good business for both, the press and the professor, print some of these Spanish textbooks.

An excellent manual used in English, and the translation into Spanish in its $5^{\text {th }}$ edition is Albert R. Jonsen, Mark Siegler, and William J. Winslade, Clinical Ethics, ${ }^{22}$ a manual of only two hundred pages. It I important to consult Chapter 1.3 about "Care of the dying patient" when it affirms: "It is a failure to recognize that when the goals of curing are exhausted, the goals o caring must be reinforced" (p. 41). It discusses the medical order of DNAR: Do Not Attempt Resuscitation. With that the textbook discusses the typical topics of euthanasia, physician-assisted suicide, and suicide. Insists that euthanasia literally means "good death". Some of these remove the physician from direct participation. "The decision and the action of ending life remain in the patient control" (p. 138).

A useful textbook that is available to students is Jonathan Silverman, Suzanne Kurtz, and Juliet Draper, Skills for Communicating with Patients. ${ }^{23}$ It I clear who is the one communicating: the physician. Under specific issues they include "Breaking bad news" (pp. 224-233) particularly useful. The textbook does not deal specifically with endof-life situations. A book even more important is How Doctors Think by Jerome Groopman. ${ }^{24,25}$ But students do not use this English edition because is not in the library, but it is the Spanish translation with quite a different title (the translation is): Doctor, Are You Listening to Me? (2008). In my opinion this title does not summarize well the content of this book. This excellent book is in the library, and recommended, but has not been read by anyone. See especially Chapter 10: "Al servicio del alma" (pp. 227-250), and "Epílogo: Las preguntas de un paciente" (pp. 251-259). My question is: how such an original an important book, translated into Spanish, and recommended for the course on Ethics, has never been read by anyone in the Medical School?

Surgery, anesthesiology, and reanimation: There are some ideas about a non-authoritarian model of medical relationship (patient/ physician) in emergency medicine, such as in the textbook of José M. Nicolás, et al. (eds.), Enfermo crítico y emergencias ${ }^{26}$ especially chapter 86 on the critical patient (pp. 901-906) in which it distinguishes between palliative sedation and terminal sedation. See also chapter 87 on "Comunicación con el enfermo crítico y la política de visitas en la UCI" (pp. 907-913). It deals with communicating the "bad news" (written by Assumpta Ricart). It proposes the methodology "Spikes" to help in that process. The chapter is in favor of the presence of the family during the hospitalization and at the ICU.

${ }^{5}$ Even J. Surós is a physician at San Diego, California. 
The emergency medicine textbook more complete is the Tintinalli's $\mathrm{s}^{27}$ in its seventh edition, with more than two thousand pages. But this is a textbook about emergency care and so there is little on the end-of-life care. In Chapter 17, on "Ethical issues of resuscitation" (pp.97-98) written by Catherine A. Marco proposes, "withholding resuscitation efforts on patients in certain clinical settings with a low likelihood of non successful resuscitation" (p. 97). She is also in favor of the family presence during resuscitation. Chapter 297 is about "Grief, death and dying, DNR/DNI orders: Delivering effective death notifications in the Emergency Department" (by Cherri Hobgood, pp. 2,017-2,021). It accepts that "Death notification is perhaps the most difficult, emotionally laden communication that physicians must perform" (p. 2,017). It proposes the GRIEV ING method for the delivery of death notification in nine stages. She is in favor of families being allowed to be present in the resuscitation. It is even more important during pediatric resuscitation, allowing parents after death holding or bathing their child. And to be prepared for responses of anger, guilt, and despair.

\section{The discourse in specializations}

Psychiatry: Because of being a psychological and humanistic discipline I would expect a collection of books or chapters treating the end-of life of any patient, no only of mental patients. But this is not the case. Some textbooks - mainly United States textbooks- present some ideas about the end-of-life care and not only about patients with mental disorders. The difference in the extension, quality, and modernity of foreign (mainly from the United States) textbooks and local Spanish textbooks is very high. Foreign textbooks mention and discuss about death and dying, communication physician/ patient, as well as suicide. This difference can be explained by the traditionally underdevelopment of most textbooks on psychiatry (and psychoanalysis) during Franco dictatorship (1936-1975) in Spain.

Psychiatry is taught in only one course, in the fourth year. The local textbook is Julio Vallego and Carmen Leal (eds.) Tratado de Psiquitría, ${ }^{28}$ in two volumes, 2,576 pages in its $2^{\text {nd }}$ edition, with 171 chapters. The author is the professor of psychiatry in Barcelona, and the co-author is in Valencia. That volume of pages hides the low quality of education on psychiatry in the Spanish medical schools. The textbook includes everything, in a supposedly rational way... except that it does not include death and dying! It includes more biological psychiaty than a psychoanalytical approach. ${ }^{29}$ Chapter 25 by J. Guimón is the exception and perhaps the explanation. Chapter 122 deals with the "General aspects of ageing" (pp. 1,689-1,708) but it refers to bio-medical changes. A shorter textbook is also by professor Julio Vallejo (ed.) Introducción a la psiopatología y la psiquiatría $\left(8^{\text {th }}\right.$ edition in 2015), ${ }^{30}$ which includes the work of 63 authors, and a total of $688 \mathrm{pp}$. Chapter 38 deals with "Psychiatry in the old age person" (pp. 620-653); but it is a medical-clinical chapter. Only at the end includes a few paragraphs on the psychological problems of people taking care of old age persons (pp. 647-648). Spanish textbooks of psychiatry do not cover the end-of-life care.

Foreign textbooks, used in Spain, include some information and ideas about the end-of-life. The students use the textbook by Benjamin Sadock, Virginia A. Sadock, and Pedro Ruiz, Sinopsis de psiquiatría: Ciencias de la conducta. Psiquiatría clínica $\left(11^{\text {th }}\right.$ edition in 2015 , with 1,469 pages). ${ }^{31}$ It includes some observations about suicide. Chapter 34 is about the end-of-life., covering all the usual topics: death, dying, grief, palliative care, euthanasia, and physician-assisted suicide (pp. 1,32 to 1,373). It also includes a description of the five stages of dying according to Elisabet Kübler-Ross. ${ }^{8}$ It even writes about mystic experiences around death. The book includes a discussion of grief. And discusses communication patterns (including how to tell the bad news). It also presents some ideas about palliative care. It is in favor of dying at home. About pain and sufferance includes the use of drugs. Discusses medically attended suicide. But globally this book is still presenting a care model of passive patients and active (authoritarian) physicians.

Still in use, after two decades, is the textbook edited by James R, Rundell and Michael G. Wise, Textbook of Consultation-Liaison Psychiatry. ${ }^{32}$ It includes a chapter (9) on "Suicidality" (sic). Chapter 34 is about "Psychiatric issues in the care of dying patients" (pp. 804831). This chapter has a first part on "The concept of an appropriate death", in which they recommend "to reach meaningful goals - even though limited- such as attending a graduation, marriage, or birth of a child as a way to provide a sense of continuity into the future" (p. 806). The psychiatrist then discusses the "assistance to patient and family in dealing with the existential crisis". The book discusses the conflicts between patient, family, and staff. The text also dedicates some time to three typical complex situations: resuscitation, withdrawal of life support, and physician-assisted suicide. The coverage of problems is wide and excellent. It includes, at the end, a section on "Staff issues in care of dying patients" (pp. 825-827). It discusses under-involvement as well as over-involvement by the staff members. The last ideas are a happy ending: "caregivers experience significant stress in the care of dying patients; however, the reward of working with these patients outweigh the stressful aspects" (p. 827).

Legal and occupational Medicine: The standard textbook of Legal Medicine is the one edited by professor Juan A. Gisbert. ${ }^{33}$ In includes the legislation in Spain about the cadaver. It includes information about death, and the dead person, but nothing really about the care at the end-of-life. Chapter 16 is about "Death as a social phenomenon. Euthanasia and distanasia" (pp. 143-151, written by A. Luna and E. Osuna). It discusses the social and cultural determinants of the endof-life. It describes the change from a traditional society to modern (an technological) one. It is part of a process of depersonalization and massification - according to the authors- where the patient is more alone. The chapter discusses euthanasia, and its different forms (passive, active and at a distance). The personal opinion is unclear, but mainly opposed. But this chapter is discursive, say obvious things, many of them stereotypes, and it does not elaborate a MMD (modern model of death). The students also use the English textbook, by Pekka Saukko and Bernard Knight. ${ }^{34}$ But it is technical, and reduced to the external causes of accidents. For Occupational Medicine the students use mainly the encyclopedic textbook edited by Jesne Mager Stellman, Encyclopaedia of Occupational Health and Safety, ${ }^{35}$ published by the International Labor Office (in Switzerland). In spite of the impressive size of the book there is nothing about the end-of-life.

Toxicology: There is a Latin America textbook of toxicology used by the students: Darío Córdoba. ${ }^{36}$ It includes a chapter (108 "Suicidio" written by Ramiro Vélez, pp. 818-820) with an old fashioned and very negative view of suicide. The author is a psychiatrist at the Pontificia Universidad Javeriana, in Bogota (Colombia).

Preventive Medicine, public health, and applied statistic: Surprisingly all the textbooks about Preventive Medicine and Public Health do not deal with the end-of-life. In public health in Spain there are mainly two alternative textbooks. One is the traditional conservative ${ }^{10}$ and the other is progressive and "leftist". ${ }^{37,38}$ They say nothing about death and dying, or about the end-of-life care. The most complete and widely used by students is the first, the textbook 
of Piédrola. ${ }^{10}$ There is practically nothing about death and dying. The most important information that the book provides to the students is that "death in Spain fundamentally happens in aged persons" (sic p. 997). Important discovery! And there are 12 editions, covering from 1962 to the last edition in 2015. The Piédrola can be considered as a conservative book, written only by Spanish professors of public health. The alternative is a textbook written mainly by outsiders, assistant professors of public health in Spain. The book is F Martínez Navarro, et al. Salud Pública (also a big book of 915 pp.). ${ }^{39}$ The textbook gets legitimacy by the collaboration of some professors of History of Medicine, as Marcet or López Piñero. This textbook tries to present a modern vision of public health, more leftist, what they call the "enfoque salubrista". Chapter 27 presents the "Education for health" (pp. 498-526), defending an education that is participative, critical, and free. But this chapter does not say anything about the end-of-life. Its mentions Thomas Khun but no Kübler-Ross. ${ }^{8}$ There is a third public health textbook from Universidad de Navarra, the main Opus Day University in Spain. ${ }^{40}$ There is a chapter (52) on the health of the old persons (personas mayores in Spanish) but it does not say anything about death and dying. Textbooks of statistics do not deal with death and dying. Except that they discuss the life tables, life expectancy, and death rates. See for example the textbook of Ronald N. Forthofer et al., Biostatistics. ${ }^{41}$ But it is technical and reduced to external causes of accidents.

Oncology: The textbooks about cancer deal with a special type of patient: one that usually knows when she is a terminal patient, or at least when there is no return to hold "normal life". At the end of cancer, death can be predicted with some accuracy. Being so, is not surprising that oncology textbooks deal with death and dying. Cortés-Funes and Colomer, Tratado de oncología ${ }^{42}$ is a massive textbook with two volumes, 2,258 pages long, and 139 authors. It is a remarkable effort of coordination. At the end of the second volume, chapter 99 deals with the patient with a terminal illness. It is written by three medical doctors - Manuel González, César Gómez, and Álvaro Pinto- of the Autonomous University of Madrid (UAM), and La Paz Hospital (also in Madrid), both excellent institutions. In this final chapter they accept that care should not be only medical, but also psychological, social, economic, and even spiritual (page 1,087). But this statement is not well developed in the textbook. They begin referring mostly to pain. The book considers that reducing pain is the goal of $60 \%$ to $87 \%$ of terminal patients (what accuracy!). The book focuses on reducing pain using different stages of drugs. Within the terminal stage "agony" is defined vaguely as "the proximity of death", or the last 2-3 days of life. In those days (only on those two days?) the obligation is the comfort of the patient. The book recommends several tasks at that time: to increase the contact with the patient, minimal surgery intervention, the patient should be always with somebody, no feeding (except if the patient asks for it), and offer the patient spiritual help. Very important is to avoid delirium. Also at that time it is necessary the care of the family (not only of the patient), and later on helping them with the stage of grief. In the whole process is important to reduce the anxiety of the family. A difficult time is the "death rattle", around 16 to 57 hours before death. But the textbook is against a simple definition of "terminal patient".

After approximately two thousand pages of oncology, this book is good in defining that the main goal is to protect the patient. That means using drugs to reduce pain, with the minimum dose possible, and making sure they are reversible. It defends a model in which medical intervention is kept to a minimum in order to maintain the quality of life of patients. For that goal the book is in favor of continuous care (of the patient) and also care of the family. The model presented is progressive, even if it does not propose a patient-controlled model: "The integral care of the patient, taking into account the physical, emotional, social and spiritual aspects according to each individual; and that the patient should take decisions over all treatment" ( $p$. $1,100)$. But this principle of patients taking decisions (and control) is at the end of a very long textbook, written by many different authors, and not developed earlier or fuller. ${ }^{43}$

There is another chapter, number 98, about the communication with the patient, written by the same three medical doctors. The title tells the story: they defend communication with the patient (from the medical side) not sharing decision power, and not the control of the patient over the situation. But the medical textbook accepts that for physicians it is important to listen. They also write about how to deliver the "bad news", without loosing hope. The patient should have the information, not necessarily the family. And if the family receive information is better from the patient. The textbook centers on the vulnerability of the sick person; initially and also when the cancer begins again. It is the patient who asks "difficult questions" which should be answered with truth and hope, never lying. The medical textbook recommends to "smile and look at the eyes" (p. 1,076). It is important then to know what the patient knows about her illness. It is not convenient to tell the patient when she is going to die. ${ }^{44}$ Patients can be "difficult", but - according to the book- there are different kinds of difficult patients: (1) patients that say no, (2) patients that are fighting back and are aggressive, (3) patients that are isolated and feel depressed, and (4) patients that ask difficult questions, like "am I going to die?" But in all cases the textbook recommend to avoid the "conspiracy of silence" (pp. 1.081-1,082). This is usually the case when the family has information that the patient ignores. Better always to give all information to the patient, and to ask her to inform the family. The worst scenario is when the patient looses control. Taking a Pollyanna attitude, the textbook sees that suffering is an opportunity for the patient to ask herself about the meaning of life. The book does not continue with this slippery idea, which goes towards a Christian approach of the end-of-life. Medical textbooks -in general- are very careful not to mention religion, or the afterlife. However, the glorification of suffering is a close idea. At the other side of the social spectrum using internet and the www there is a possibility for improvement. Even the textbook does not mention the association of patients with the same illness. The web also helps to get information, and to control the treatment over the limited information usually offered by the medical system.

One of the most complete textbooks on oncology is DeVita, Hellman, and Rosenberg's textbook..$^{45}$ The manual is massive: 2,234 pages in only one volume. The final chapters are quite relevant for the study of the end-of-life. Chapter 150 is "Communicating news to the cancer patient" (by Eric J. Cassell). It defines the main change in the care of terminal patients: "The goal of cancer treatment, in general, has long been to improve survival. Recently, this has been modified by the addition of the goal to treat without decreasing quality of life" (p. 2,130). It does not specify how recently, or who has modified it. More clearly: "People do not get up in the morning just to survive" ( $\mathrm{p}$. 2,130). ${ }^{6}$ This chapter presents a new model of relationship: "You are telling the patient that you and the patient are a team, that the patient is not alone" (p. 2,132). However, the model is still traditional. More modern would be the patient telling the physician that he is not alone. Cassell recommends to the doctors: "Do not answer a question that has not been asked" (p. 2,131). The goal is a "Good Death", to use the

${ }^{6}$ Eric J. Cassell is an emeritus professor at Cornell University. 
expression of this textbook: "the team must engage in new types of conversations with patients and their families and among themselves" (p. 2,134) That means that in this "benefactor model" the team does not really include the patient. Team refers only to professionals that work for the patient. The textbook favors more conversation with the patient, and early palliative care. Chapter 151 , in the same textbook De Vita, is about "Specialized care of the terminally ill" (by Robert S Krouse, and F. Amos Barley). An important reflection is that we owe to cancer that the terminal patients and their problems are openly discussed on medical textbooks. Again, textbooks belonging to courses that are most expected to treat the problems of the care of the end-oflife do not say much. But in some illnesses the idea of comfort care is established for the patient, and families are counseled about the dying process of their relative. Also the ideas in the oncology textbooks are more modern, and advanced that the few references in other books. Obviously it depends on the inevitability of cancer patients to face death, and to be defined more exactly as terminal patients. There are patients that suffer more pain, and during a longer period of time..$^{46}$

However, not all oncology textbooks include information about the terminal patient. This lack of discussion happens even in very comprehensive textbooks (more than two thousand pages long), in English, such as Holland-Frei (Kufe 2006) ${ }^{47}$ Spanish textbooks like M. Gonzáles Barón (2010) ${ }^{48}$ - Present some ideas, but it is unclear and baroque. Chapter 54 of the textbook is on "Ética y enfermedad terminal" (pp. 897-910) by J. D. Muñoz and M. Gozález Barón. The style is a typical discursive style: long sentences an vague ideas, with ambiguous meanings, many adjectives, and a patronizing attitude toward the patient. It also includes a certain spiritual attitude. Never proposes a MMD.

Obstetrics and gynecology:_Textbooks of obstetrics and gynecology usually end not by terminal (female) patients but by gynecologic oncology, with the discussion about different types of cancer. The main approach of those textbooks is the medical problems of women and reproduction. They never focus on the terminal female patient. See for example J. González Merlo et al ${ }^{49}$ textbook on Ginecología.

International textbooks are more explicit. For example, students use Larry J. Copland Textbook of Gynecology. ${ }^{50}$ Chapter 19 deals with "Aspectos éticos en ginecología" (by Fredrick R. Abrams). Chapter 22 is about "health in lesbian women" and "therapeutics perspectives for sexual minorities" by Katherine A. O'Hanlan an Demetra L. Burrs (pp. 533-549). No chapter like this is in the Spanish textbooks. It mentions that a special problem among lesbian women is obesity. The textbook explains that problem as a rejection of the sexy model of women: "slim waists, big breasts, and long hairs" (p. 538 ). This textbook is very progressive an modern. The chapter is an example of learning for the present generation of medical students, both females and males. The last chapter of the book chapter 69- is one of the few exception about the end-of-life care for women. It is about "Palliative care and care of the terminal female patient in gynecology" (pp. 1,615-1,624 by Joanne M. Cain). The main objective is the reduction of pain and sufferance of the (female) patient. Also to get a functional quality of life in terminal patients. The textbook affirms that in terminal cases new pains happens. It is also probable the need to intensify painkillers. If the patient is at home the family needs to get full information about what to expect in the last few days/hours of life. The goal is to decrease (and control) the pain and sufferance of the patient and also of the family. They need to be assured that both patient and family will not be abandoned. The principle of autonomy of the patient can conflict with her family. The health system is there to help the patient to get, and probably to express, a sense of meaning of life and ending (both to the patient and family). But this "meaning of life" is not well defined in the medical textbook. This final chapter calls at the end the attention to the problems of the health professionals attending terminal patients. The stress is so high that they can easily fall into drug addiction, or well to develop cynicism or devaluing of individuals. $^{51}$

Some medical schools do not recommend reading or studying books from other medical schools. Anyway, medical students do not have much free time. This is clear in the tension between Barcelona and Madrid. For example the textbook of Botella and Clavero, ${ }^{52}$ from Universidad Complutense de Madrid, even it reached its $14^{\text {th }}$ edition (in 1993), is not recommended in Barcelona. There is nothing in that book about end-of-life care. In part the rejection is because the book is especially conservative. In the chapter 80 on contraception it favors sexual abstinence. It affirms that "a sexual abstinence of two or three weeks per month [sic] perhaps is good for dream and love" (p. 1,023).

Pediatrics: Perhaps the biggest American style medical textbook is the so-called Nelson, about pediatrics. The reference is located in Robert M Kliegman ${ }^{53}$ in the famous Edition 20, with near 3,500 pages (sic). The first edition was published in 1959. It is an excellent textbook, at the highest of the state-of-the-art textbooks, produced by the best research universities in the United States. They are also in collaboration with the best-specialized presses in the world: in this case Elsevier. ${ }^{54}$ Pediatrics is a special case for the end-o-life care model, because the patient is not always rational or autonomous. "The pediatric clinician has an independent fiduciary obligation to act in a younger child's best interest that takes moral precedence over the wishes of the child's parent(s)" (p. 27). So in a pediatric model of care the health professional represents her own professional standards and interests, and in addition she is a moral defender of the child. I want to call attention to an excellent table with very useful information in the book: Table 4.1 "Cultural values relevant to health and healthseeking behavior" (pp. 34-35 of Nelson). It is a summary of ethnic difference in relation to health, produced by Linda Kaljee and Bonita S. Stanton. Linda \& Bonita have done a good job to synthesized ethnical differences. It would be a good idea to develop a table like this but for adults, and for end-of-life processes. The book opposes the practice of withholding information from children and parents about the child's diagnosis and prognosis. "Children have the right to know their diagnosis and should be informed early in their treatment" (p. 109, Chapter 18 about "Loss, separation, and bereavement"). Pediatrics is a source of information about the end-of-life care, but applied to the special care of children. The section on "Role of the pediatrician in grief" is excellent but brief (pp. 110-111). In the international textbooks on pediatrics they even care about the pain and stress of the newborns (see chapter 67 in Cloherty, et al, eds. 2012, pp. $870-885)$. There are local textbook of pediatrics, with the new style of United States textbooks, like Manuel Moro, Serafín Málaga, and Luis Madero in the textbook Cruz, ${ }^{55}$ with the eleventh edition in 2014, and more than 2,500 pages. However, this massive local textbook of pediatrics says very little about terminally ill children, an their endof-life care. See chapter 59 about communication it the family (pp. 308-310). They show vague ideas of collaboration of professionals, and with the family.

Hospital: In the last (sixth) academic year the students have a brief period of work in a hospital and in a general family medicine care 
unit. For those two experiences they also have some textbooks recommended. In the textbooks about hospitals, management of those hospitals, and other aspects of the hospital organization there is nothing about death and dying. It is a "no problem".

The medical school does not include a compulsory course on geriatrics or gerontology. But at least they recommend the reading of a Mexican textbook: Rosalía Rodríguez and Guillermo Lezcano, Práctica de la Geriatría. ${ }^{56}$ It includes a Chapter 2 about "El final de la vida: Como enfrentarse al proceso de morir" (pp-. 732-743). She recommends that terminal patients should not interrupt their daily life; but at the same time that patients should not die with pain. She recommends the medical students: "you need to see with your heart, to suffer with the patient" (page 741). It is a very Latin American expression. The textbook presents a discursive and paternalistic tone in which doctors take decisions in favor of patients, and doctors are also caring for relatives. But it is not a democratic relationship, nor one of the patients taking control over their own life. Anyway, this textbook is an outsider in the medical career. There is only one textbook, but surely being recommended for the nursing students: Jeffrey B Halter, et al..$^{57}$ in 2017 . As I said, there is not a compulsory course on gerontology at the medical career. There is only an optional course. Anyway, I propose to read chapter 26 on "Team care". It is in favor of the "geriatric interprofessional team", IPT, a team of health care personnel no including necessarily the patient. In spite of being a very recent, an modern, textbook (2017 in its 7 th edition) it proposes still a benefactor model of care.

There is no (compulsory) course in the medical studies about palliative medicine. Therefore there are no recommended textbooks in this library section. But the Medical Library has four textbooks that are very interesting about palliative care. There is one (by Gómez $1999)^{58}$ called Medicina paliativa en la cultura latina (sic) or Palliative Medicine in the Latin Culture. It includes a chapter 2 on "El médico ante la muerte de su enfermo" ("The physician in front of the death of his patient") with literary overtones. Another Spanish textbook on palliative care is by M González Barón ${ }^{59}$ but specifically about the patient with cancer. Then there are two excellent international textbooks, the Oxford one,$^{60}$ and the Palliative Medicine of Declan Walsh. ${ }^{61}$ Walsh acknowledges at the beginning the influence of Dame Cicely Saunders (1918-2005), founder of the hospice movement, and of the St. Christopher Hospice, in London, in 1967. In the section of "Pain" in the library there no books recommended as textbooks.

Family and community medicine: There are textbooks that present a health care system more centered on the patient. But those textbooks are at the very end of the career, and no as really courses (with lectures and exams) but in the form of practices. One example is the textbook of Francesc Borrell on Práctica clínica centrada en el paciente. ${ }^{62}$ However, in spite of the title and the approach (centered in the patient), the book does not include anything about the end-of-life care. This is surprising because it could have been the best textbook to develop a discussion on death an dying, an a new model of (good) death.

International textbooks include more information. It is the case of the textbook on "family medicine" edited by Robert B. Taylor. ${ }^{63}$ A special case is chapter 33 on "El paciente suicida" (pp. 320-324). It discusses different measures for the prevention of suicide. It even includes a section on "suicide of physicians", advising doctors to avoid social and emotional isolation. More important is chapter 62 on "Atención al paciente terminal" (pp. 572-578) written by Frank S. Celestino. It begins by a discussion on the "dignified death" including "spiritual peace". It discusses the options opened to the terminal patient: home/hospital, palliative care, medically assisted suicide, autopsy, donation of organs, pain control, the will, control of grief, an so on. It includes some ideas about the breaking of "bad news". It favors telling the truth, always including optimism and hope. Being asked by the patient (or the family) it recommends a conservative estimate of length of life, to congratulate the patient and family if she survives it. The chapter presents the five stages model of KüblerRoss. The patient needs to be assured that she will not be abandoned. The terminal patient needs physical contact showing affection. The chapter explains the present change from cure to care. At the end-oflife what is important is palliative care, control of pain, and a good quality of life. Celestino is in favor of an active life until the end. The text describes the "palliative care units" (PCUs) in United States. But even the book is translated into Spanish it does not say anything about the situation in Spain. In United States there are about 2,000 PCUs attending terminal patients, $80 \%$ of them with metastasis from cancer. In modern times many patients express their "last wishes" especially about the continuation, or not, of medical treatment, under several circumstances. The textbook suggests that a frank discussion about terminal care should be done early, right after the diagnosis. Later, it is complex to evaluate the capacity of decisions of the patient. The reduction of pain is the most important at the end, planning a detailed treatment with an "analgesic scale". This is in reality a proposal of the World Heath Organization. The text is favorable to the use of morphine; and even a terminal sedation of the patient. In these textbook "sedation" is usually an expression implying that it is no reversible. Celestino mentions that the hospice system and the palliative care system (in the United States) offer grief help for 13 months. In this chapter there is a special section about terminal children. In these cases it is a good idea to experience the end-of-life at home. Other siblings should be invited to help, and they should also receive some care. The model proposed by this textbook is a system that adapts to the needs and wishes of terminal patients. The patient should have options; and to keep the control (or the feeling of control, says the book) over the whole situation. I should add here that this is the best I have read in the textbooks of the medical school about the end-of-life care.

Veronica Casado ${ }^{64}$ mimics Taylor's book. It has a title that coincides with a course in the medical school: Tratado de medicina de familia y comunitaria. It is also massive: 2,563 pages. Chapter 51 , towards the end, is on "Atención al paciente terminal, el duelo, y el cuidador" (pp. 2,315-2,358) by Miguel Á. Benítez-Rosario and Toribio González (both from Santa Cruz de Tenerife, in the Canary Islands). It covers what the title says: care of the terminal patient, grief, and personnel in charge. The textbook defines "terminal patient" as a person with a prognosis of 6 months or less of life. Agony is considered the last one to five days. The text begins by the definition of palliative care, following the WHO. It advises to believe in the patient when saying she is in pain. It presents a catalogue of medications against pain. Benítez and González are in favor of the use of morphine before the agony. The information in the book about painkillers is extensive. On death and dying they discuss the model of Küble-Ross in five stages. It is an interesting approach but they do not propose a MMP. It is a detailed care of the terminal patient but not including the patient as part of the team, nor allowing the patient to keep control of the situation. They favor that information should be given to the patient gradually. Before, the doctor should find what the patient knows about her own illness. There is a section on the "conspiracy of silence", when the family occults information about the diagnosis or the prognosis (or 
both) to the patient. The medical model is patronizing, but benefactor It is a model in favor of the patient, but without the control of the patient. This chapter insists that the system needs to take care of the patient but also of the family. Grief lasts one to three years.

Both Taylor and Casado's books are quite comprehensive. However, I doubt that students read these books, even when they are recommended, because "Family and community medicine" in the sixth (and last) year of studies is considered as practices, not as a regular course. And that is a pity because both textbooks - the English one and the Spanish one- are interesting and cover some ideas about death and dying. They provide the most detailed information about terminal patients, in the whole medical studies. This chapter insists that the system needs to take care of the patient but also of the family. Medical students should begin their career by reading these chapters that deal with the terminal patient. To plan for end-of-life decisions is not stimulated by doctors. It is important to prepare medical students for future treatment decisions. Advanced care planning is lacking. At the end-o-life stage there is a coincidence of the most modern medical technology and pharmaceutical discoveries with the traditional goodbye family rituals. Death has also changed from a collective multi-generational experience to a private experience. At the very end of life, the technological medical system is of little help except for painkillers.

The main textbook about primary care is that of Amando Martín Zurro $^{65}$ and J. F. Cano on Atención primaria. It includes a chapter (70, pp. 1.671-1.694) on "The terminal patient" written by three physicians: Ledesma, Roca, and Porta. They affirm "The promotion of autonomy and dignity of the patient should direct the therapeutic decisions. This principle is only possible if the therapeutic objectives are elaborated with the patient" (p. 1-673). In addition, this book treats extensively the topic of pain, and the use of medicines to control pain. The same chapter has a section on "The last days: Care in the agony" (pp. 1.687-1.689): "in the last hours all patients require a specific and permanent care by professionals and trained relatives. You cannot improvise" (p. 1.687). It includes many ideas about care for - and by- the family. The book develops well ideas about how families can collaborate. "The psycho-social attention to the family is essential for the success of terminal patients", "the caring team and the family should work together" (p. 1.692). For Spanish medical textbooks, this one is quite innovative, even it is still far from an MMD.

\section{Discussion (what medical students should learn)}

I have the suspicion that in Barcelona there was never and open and free discussion about what medical students should learn at the Medical School. The medical studies reflect the power of the different Departments, as well as the divisions of the teaching Hospital Clínico. They also reflect the international cannon of medical studies. In addition, death is a taboo, and then the end-of-life is absent from most of the medical textbooks the students use in the 44 courses of the MD career. This is so even from the courses you could expect that medical students can learn more about the end-of-life, and the care they should apply in that process, especially to terminal patients. The medical institutions and professions are of little help at the end. Atul Gawande, ${ }^{66}$ in his book Being Mortal: Medicine and What Matters in the End (Angell 2015) criticizes "a society that faces the final phase of he human life cycle by trying no to think about it". ${ }^{67}$ But medical students need to think about.

Popular wisdom indicates that the care you will receive at the end-of-life depends from the number of children you have, and if you have at least one daughter. In most cases death comes after a rough an bitter medical struggle. Often medical treatment, even surgery, continues when it is really not needed. Pain and suffering is usually a consequence of that extra medical treatment. Gawande affirms "More than $40 \%$ of oncologists admit to offering treatments that they believe are unlikely to work". ${ }^{67}$ The reason is that "it is much easier and faster to offer one more technological fix than to talk about death with a dying patient" (2015: 21) ${ }^{68,69}$ These ideas need to be discussed in the medical textbooks, so medical students learn about the end-oflife care. The most important lesson is that the dying process should be, at least, without pain and suffering. Patients should decide by themselves. Dying and death are not medical problems but human problems. They should be discussed like that in the medical textbooks.

But even taking into account some progress in certain specialties (such us in oncology, and in family medicine) we are still lacking a model of patient/physician relationship that gives patients the control over their own illness, and so over the end-of-life process. There are some patronizing viewpoints from some medical doctors about how to make the end-of-life better for their patients. It is a "benefactor model", that in a way is better than the "authoritarian model" of the past. But medical students are never learning, in the courses, and textbooks, a modern model of managing death and dying giving patients the control over the manner and timing of their endof-life. Therefore, there is also not a model of care for the end-of-life. Medical schools - at least in Spain- have not yet began to develop an appropriate end-of-life care model. This is taking into account that the Clínico Hospital, in Barcelona, together with the Medical School, are one of the most advanced models of medical learning and advancement of medical knowledge in the country. There is a risk: that physicians do not take responsibility about terminal patients, and leave them to social workers, nurses, palliative care units, hospices, and other professionals and institutions - and the family! This is happening already. For example, Columbia University Press has a collection of books on "End-of-Life Care: A Series" ${ }^{70}$ Most of books in the collection are not for physicians but for nurses and social workers.

Very little research is being done presently, in Spain, about the end-of-life patients, as well as models of care of death and dying. It is a double problem that needs to be developed using advanced research and teaching. The debate of how to have a better death is more in the mass media than in the medical schools. ${ }^{71}$ The proposal of the mass media - such as The Economist (2017)- is to set up an honest an open conversation with the dying. The problem is that "most doctors enter medicine to help people delay death, not to talk about its inevitability [... ] Most oncologists, who see a lot of dying patients, say that they have never been taught how to talk to them" (The Economist 2017: 9). Money is many times the problem. Medical doctors are paid for "medical intervention" and not for having conversations with terminally ill patients, holding hands with them. ${ }^{72,73}$

What is lacking in the medical textbooks is a modern model of death (MMD). Some reports inform that in developed countries people spend between eight and ten years seriously ill at the end of their life. It is enough time for planning. But reality is that at the endof-life most patients are alone, confused an in pain (The Economist 2015: 45). The first proposal is to improve the patient/doctors communication. Secondly, that the health care systems (both public and private) insure payments to doctors for talking to terminal

patients. Hospitals should also be paid for preventing pain. Thirdly, that the laws of the countries allow for patients to take decisions, reject 
treatment, plan their death, including physician-assisted suicide, and some other forms of euthanasia. ${ }^{74-76}$

The MMD is in reality a plan for a "good death", but also a message to doctors about a better way to care for the dying. In a summarizing way this model - that needs to be developed in the medical textbooksshould include the following actions: ${ }^{7}$

1. Total control of patients over their lives, until the very end. This will include the capacity to reject treatment and surgery. Or hospitalization.

2. To have early patient/doctors conversations about the end-oflife are more productive. Before they become terminal patients and the end-of-life. Thus it is easier to return to the conversation when it is most needed.

3. It is necessary to talk specifically about what the terminally ill patient understands about her condition. And how much the patient wants to know. This is difficult to evaluate by both patients and doctors

4. It helps to listen to - or read- together (patient and doctor) experiences of death. The system can facilitate internet connections and blogs about her condition. And if necessary computers and wifi connections.

5. Offer the patient an honest prognosis: how long she is going to live, and in what conditions. Take into account that doctors usually overestimate the life span of their patients (by about double). Develop skills of how to talk about death, not only about breaking bad news.

6. Ask the patient what she wants to tell the family (the different members of her family) about her illness and prognosis. Inform the family - whenever possible- always with the patient present Never talk to the family secretly, even in fatal prognosis.

7. Understand the goals of terminal patients. Propose trade-offs she is willing to make, informing her about the risks. Find out what patient would like to do most. Organize for them the trip.

8. Begin palliative care soon (it is demonstrated that patients live longer). Set a plan to reduce suffering, pain, and stress. Not to suffer unnecessarily at the end.

9. Reduce or even cancel drastic treatment and surgery that is not really needed at the end. The problem is always to define more exactly "the end".

10. Help patients to feel ready for death. In case of believers to die at peace spiritually. But never insist in spiritual help. Some nonbelievers tend to return to religion when approaching the endof-life.

11. Invite the family to be present in the resuscitation when necessary.

12. Assist the patient to die with dignity; dying looking good. Find out the way she interprets "dignity". Be alert of the multicultural differences. Never allow her to die alone, confused, or in pain, if it is possible to reduce these three conditions.

13. At the end, assure the patient that you will take care of the family, and the expressions of grief, after her death. An do it.

Last but not least, what medical students should learn - to be good medical doctors in the future- need to be written in the medical

${ }^{7}$ I have considered here that the patient is a female. textbooks. Unfortunately in the medical school there is not a course on death and dying, no end-of-life care, There are 44 courses than are being taught in the six years of the medical career. In-depth discussion about the "good death" should be included in several of the medical textbooks. That way the student will learn about the end-of-life care from different perspectives. At present, the modern model of death (MMD) is totally absent in this research undertaken by me. ${ }^{77-79}$

\section{Conclusions of the paper}

I have done a research of the 2,868 textbooks of the Medical School (of the University of Barcelona, Spain) being used by the students during the six years of their academic MD degree. They cover the recommended references of the 44 courses. The books are clearly marked in the Medical Library. After the discussion, this paper reaches seven main conclusions.

Death and dying form a taboo that is also present in the medical textbooks. Most of them never mention death or dying. Even those courses that are closer to this topic - like introduction to health, psychology, public health, hospitals, and so on- say very little about the end-of-life.

Textbooks that deal about the end-of-life are mainly in medical areas were the definition of "terminal patient" is easier, and many times is obvious, like cancer/oncology. In that way cancer has made a favor to medical education in general.

1. The few textbooks that deal with death and dying define a patient/ physician relationship that is authoritarian, conservative, and out of date. Other textbooks favor a "benefactor model", with doctors doing the best for their patients. There is not a model establishing the control of the patient of her illness, manner and timing of her dying process. The lack of that theoretical model I think is the main problem for establishing a proper end-of-life treatment, care, and management.

2. Care at the end-of-life is even more absent in the textbooks analyzed. There is some discussion about assisted suicide, or about the medical aspects of the dying process. But there is very little about care of the patient, and the control of that care process by the patient herself.

3. Medicine and health are dominated by the traditional medical model. As a consequence of not teaching about the end-of-life, or the lack of education that medical students receive about care, tend to generate in the whole health system a model that is conservative. It has not evolved yet towards a care model closer to the patient, and controlled by the patient.

4. Probably in the future the-end-of-life care will be assigned to social workers and the nursing profession; so the medical profession is escaping from that responsibility.

5. In Spain, at present time, we do not see textbooks offering religious (Christian) solution of the end-of-life, nor the suffering, nor care. The textbooks for medical students are "scientific", avoiding any reference to the "soul" and "afterlife". Textbooks that are moralistic are out of use.

The present research has been done on one Medical School, and in only one country. However, the Medical School (plus teaching hospital) is a very prestigious one, and also very advanced. Most textbooks used by students are international textbooks in English (from United States) or translations of those into Spanish by the same medical presses. These conclusions refer only to this case. But 
I think that the results can be generalized to many other Medical Schools and countries. We need more comparative research. I expect that the situation will change when in those countries (1) a modern model of care at the end-of-life is openly discussed, and (2) when the authoritarian medical model is not the dominant one in the health sector. We still need to remember often the medical motto:

Cure sometimes,

Relieve occasionally,

Comfort always.

\section{Acknowledgments}

None.

\section{Conflicts of interest}

The authors declare no conflicts of interest.

\section{Funding}

None.

\section{References}

1. Bauman, Zygmunt. Mortality, Immortality and Other Life Strategies. Cambridge:Polity Press; 1922. 215 p.

2. Bauman, Zygmunt. Retrotopia. Cambridge, United Kingdom: Polity Press; 2017. 179 p.

3. Gottlieb Robert. Back from heaven: The science" The New York Review of Books. It is a review of seven books on the topic of near-death experiences. 2014:36-38.

4. Vovelle, Michel. Mourir autrefois: Attitudes collectives devant la mort aux XVIIe et XVIIIe siècles. Paris: Gallimsrd; 1983.

5. Holt, Terrence. Internal Medicine: A Doctor's Stories. Liveright; 2014; $273 \mathrm{p}$.

6. Mitford, Jessica. The American Way of Death. 1963.

7. Scheffler, Samuel. Death and the Afterlife. Oxford: Oxford University Press. In: Susan Wolf, et al, Editors. Frankfurt, amnd Seana Valentine Shiffrin. It contains the Tanner Lectures on Human Values, at the University of California Berkeley. Scheffler is professor of philosophy at New York University. 2013

8. Kübler-Ross, Elisabeth. On Death and Dying: What the Dying Have To Teach Doctors, Nurses, Clergy and Their Own Families. London: Routledge. It is the second edition: the " $40^{\text {th }}$ anniversary edition". The author died in the year 2004. 1969;21(5):639-640

9. Ariès Philippe. El hombre ante la muerte. Madrid: Taurus; 1977.

10. Piédrola Gil. Medicina preventiva y salud pública. 12th ed. Barcelona: Elsevier Masson; 2015

11. Calbet, Josep M, Manuel Escudé. Història de la Medicina. Barcelona: PPUSA; 2009. 248 p.

12. Porta, Miquel, International Epidemiological Association. A Dictionary of Epidemiology. 6th ed. Oxford: Oxford University Press; 2014. 343 p.

13. Laín Entralgo, Pedro. Historia de la Medicina. Barcelona: Masson; 1978. $722 \mathrm{p}$.

14. Amigo Vázquez Isaac. Manual de psicología de la salud. Piámide 3rd ed. Madrid: 2017. $262 \mathrm{p}$.
15. Myers David G. Psicología. Editorial Médica Panamericana, 7th ed. Madrid; 2006. $741 \mathrm{p}$.

16. Myrs David G, C Nathan Dewall. Psychology. NewYork: Worth Publishers; 2015. $693 \mathrm{p}$. and appendices. It includes at the beginning an interesting contribution by Richard O. Straub on "How to be a great student and still have a life". 159.9 MYE.

17. Sahler Olle Jane Z, John E Carr. The Behavioral Sciences and Health Care. Cambridge, MA: Hografe \& Huber; 2007. 496 p. It is the second expanded edition. BE 159.97 BEH. I have consulted also the third edition, $537 \mathrm{pp}$.

18. Swartz Mark H. Textbook of Physical Diagnosis: History and Examination, 7th ed. Philadelphia: Elsevier Saunders; 2014. 825 p.

19. Taylor Shelley E. Psicología de la salud, 6th ed. Madrid: McGraw Hill; 2007. 558 p. See chapter 12 "Aspectos psicológicos en la enfermedad avanzada y enfermedad terminal" p. 315-340.

20. Surós Antonio, Juan Surós. Surós: Semiología médica y técnica exploratoria. 8th ed. Barcelona: Masson; 2006. p. 1,156.

21. Gracia Diego. Fundamentos de bioétic. 3rd ed. Madrid: Triacastela; 2008. $605 \mathrm{p}$.

22. Jonsen Albert R, Mark Siegler, William J Winslade. Clinical Ethics: A Practical Approach to Ethical Decisions in Clinical Medicine, 5th ed. NewYork: McGraw-Hill; 2002. 202 p.

23. Silverman Jonthan, Suzanne Kurtz, Julliet Draper. Skills for Communicating with Patients. 3rd ed. Boca Raton, Florida: CRC Press; 2013. 305 p.

24. Groopman Jerome. ¿Me está escuchando, doctor? Un viaje por la mente de los médicos. Barcelona: RBA; 2008. 99 p.

25. Groopman Jerome. When doctors admit they went wrong. The New York Review of Books. 2014. p. 20-21. It is the review of Terrence Holt, Internal Medicine: A Doctors's Stories. Liveright, 273 p.

26. Nicolás José M. Enfermo crítico y emergencia. Barcelona: Elsevier Masson; 2011. 1.012 p.

27. Tintinalli, Judith E. Tintinalli's Emergency Medicine: A Comparative Study Guide. 7th ed. New York: McGraw-Hill Medical. A massive textbook with 299 chapters. Now in color. 616-035.9 TIN. 2011. p. 2,120.

28. Vallejo Julio, Carmen Leal. Tratado de Psiquiatría. 2nd ed. Madrid: Marbán, in two volumes. (Volume 1 total of $1-747 \mathrm{p}$; Volume 2 from $\mathrm{p}$ 1,748-2,576), BE 616.89 VAL. With 171 chapters. 2012.

29. Sarafino Edward P, Timothy W Smith. Health Psychology: Biopsychosocial Interactions. International Student Version. 7th ed. Hoboken NJ editor. BE 159.91 SAR, Wiley. 2012. p. 528.

30. Vallejo Julio. Introducción a la psicopatología y la psiquiatría. $8^{\text {th }}$ ed. Barcelona: Elsevier España. It includes 63 authors. 2015. p. 688.

31. Sadock Benjamin J, Virginia A Sadock, Pedro Ruiz. Sinospsis de psiquiatria: Ciencias de la conducta. Psiquiatría clínica. 11th ed. Barcelona: Wolters Kluwer. 2015. p. 1,469.

32. Rundell, James R, Michael G Wise. Textbook of Consultation-Liaison Psychiatry. Washington DC: The American Psychiatric Press. BE 616.89 AMA. 1996. p. 1,171

33. Gisbert, Juan A. Medicina legal y toxicología. Barcelona: Masson, 5th ed. With 27 authors, and 99 chapters. BE 614.259 GIS. 1998. p. 1,214.

34. Saukko, Pakka, Bernard Knkight. Knight's Forensic Pathology. 3rd ed. In: Arnold editor. London: 34 chapters. BE 614.259 KNI. 2004. p. 662. 
35. Mager Stellman, Jeanne. Encyclopaedia of Occupational Health and Safety. 4th ed. Geneva, Switzerland: International Labour Office ILO, 4 volumes. With 104 chapters, containing each several articles. It also has chapter editors. Page numbers are by chapters 613.6 ENC; 1998

36. Córdoba, Darío. Toxicología. Bogota, Colombia: El Manual Moderno, 5th ed. It prints at the beginning: "El libro muere cuando lo fotocopias" BE 615.9 TOX. In spite of the editor the book is no modern. 2006. p. 1-022.

37. Bellosta, M Asunción. Sentir la muerte hoy: El género al final de la vida. Zaragoza: Prensas de la Universidad de Zaragoza, 2014. p. 237.

38. de Cervantes, Miguel. El ingenioso hidalgo Don Quixote de La Mancha. In: Arturo Pérez-Reverte editor. Madrid: Real Academia Española, and Santillana. See especially chapter 51 of the second part, "De cómo don Quijote cayó malo, y del testamento que hizo, y su muerte" "How don Quixote got sick, of his will, and his death". 2014. p. 579-586.

39. Martínez Navarro F. Salud pública. In: Prólogo de José M López Piñero editor. (Professor of History of Medicine, at the University of Valencia). Madrid: McGraw-Hill Interamericana. BE 614 SAL. 1999. 915 p.

40. Martínez-González Miguel Á. Concepto de salud pública y estrategias preventivas: Un manual para ciencias de la salud. Barcelona: Elsevier, with 68 authors and 66 chapters. 614 CON. 2013:509.

41. Forthofer, Ronald N, Eun Sul Lee, et al. Biostatistics: a guide to design, analysis, and discovery. Amsterdam. Academic press. Elsevier, 2nd ed. 6 FOR, 2007;502:312.

42. Cortés-Funes, Hernán, Ramón Colomer. Tratado de oncología. Barcelona: Permanyer. Two volumes: $1: 1,146 ; 2: 1,112$. See especially the second volume, chapter 99 on "El paciente con enfermedad terminal" (by Manuel González, César Gómez, and Álvaro Pinto) pp. 1,087-1,101; as well as chaper 98 "Comunicación con el paciente" (by the same three authors). 2009; 1,073-1,086.

43. Wilkinson, Richard, Kate Pickett. The spirit level: why greater equality makes societies stronger. New York: Bloomsbury Press; 2009:329.

44. Nuland, Sherwin B. How We Die. Chatto \& Winus.

45. DeVita Jr, Vicent, Theodore S, et al. Hellman and rosenberg's: cancer, principles \& practice of oncology. Philadelphia: Wolters Kluver, 10th ed 1st ed. 1982. 2015;2,234(153).

46. Armstrong-Coster Angela. Living and dying with cancer. Cambridge, United Kingdom: Cambridge University Press. 2004;194.

47. Kufe, Donld W. Holland-frei cancer medicine. In: Hamiltonn, BC Decker. editors. It is an pproved publication of the Americn association for cancer research. 2006: 2,328.

48. González Barón M. Oncología clínica. madrid: momento médico iberoamericana, Mainly the professionals from Universidad autónoma de madrid and la paz hospital in madrid. 2010;(2):1,032-1,073.

49. Gonzalez-Merlo JE. González Bosquet, J González Bosquet. Ginecología Barcelona: Elsevier Masson, 9th ed, BE 618.1 GIN. 2014:645.

50. Copeland, Larry J. Ginecología. Madrid: Editorial Médica Panamericana, 2nd ed, In Englih is Textbook of Gynecology, 69 chapters. 2002; 1,658.

51. Kitcher Philip. Life After faith: the case for secular humanism. New Haven: Yale University Press; 2014:175.

52. Botella, José, José A. Tratado de ginecología: Fisiología, obstetricia, perinatología, ginecología, reproducción. Madrid: Díaz de Santos, 14th ed. 80 chapters all written by the two authors. 618.1 BOT. Is not a recommended textbook in Barcelona. The first edition is from 1945. 1993:1080

53. Kliegman, Robert M. Nelson: Textbook of Pediatrics. 20th ed, Philadelphia: Elsevier; 2016. 3,473 p.
54. Elsevier. Medicine textbooks 2014-2015. Elsevier; 2014. 57 p.

55. Manuel MS; Málaga SG, Luis M. Cruz: Treaty of Pediatrics. 11th ed. Madrid: Editorial Médica Panamericana, BE 616-053.2 CRU; 2014. $2,574 \mathrm{p}$.

56. Rodríguez R, Guillermo L. Geriatrics Practice. 3rd ed. México Ciudad: McGraw Hill; 2015. 928 p.

57. Halter JB, Ouslander JG, Studenski S, et al. Hazzard's Geriatric Medicine and Gerontology. 7th ed. New York: McGraww-Hill Education; 2017 $2,064 \mathrm{p}$.

58. Gómez Marco. Palliative medicine in Latin culture. Madrid: Arán Ediciones; 1999. 1,256 p.

59. González Barón M. Palliative Medicine Treaty and Supportive Treatment of Cancer Patients. 2nd ed. Madrid: Editorial Médica Panamericana; 2007. $846 \mathrm{p}$.

60. Cicely Saunders. Oxford Textbook of Palliative Medicine. In: Doyle D, Geoffrey WC Hanks, MacDonald N, editors. Oxford: Oxford Medical Publications, Oxford University University Press; 1993. 845 p.

61. Walsh Declan. Palliative Medicine. Barcelona: Elsevier; 2010. 1,475 p

62. Borrell Francesc. Patient-centered clinical practice. Madrid: Triacastela; 2011. 39 p.

63. Taylor Robert B. Family medicine: Principles and practice. 6th ed. Barcelona: Masson; 2006. 1,283 p.

64. Casado Verónica. Treaty of family and community medicine. 2nd ed. Madrid: Editorial Médica Panamericana; 2002. 2,563 p.

65. Martín Z, Amando, Cano JF. Primary care: Concepts, organization and clinical practice. 5th ed. Madrid: Elsevier; 2003. 1,761 p.

66. Gawande, Atul. Being Mortal: Illness, Medicine and What Matters in the End. New York: Metropolitan; 2014. p. 282.

67. Angell, Marcia. A better way out", The New York Review of Books ( 8 January), pp. 20-22. It is the review of the book by Atul Gawande, Being Mortal: Medicine and What Matters at the End. New York: Metropolitan; 2015. p. 282.

68. Brim, Orville G, Howard E Freeman, et al. The Dying Patient. New York: Russell Sage Foundation; 1970. p. 390.

69. Clark, David. The Sociology of Death: Theory, Culture, Practice. Oxford: Blackwell; 1993. p. 302

70. Kellehear, Allan. The Inner Life of the Dying Person. New York: Columbia University Press; p. 264. It is one of the volumes of the "End-of-Life Care: A Series”, a collection edited by Keith Anderson. 2014.

71. Iglesias, Victoria. Pacientes que toman su última decisión. Las unidades de cuidados paliativos acogen a un tipo especial de enfermos: Los que se preparan para morir. El País. 2017; p. 28.

72. The Economist. How Life Ends: Death Is Inevitable. A Bad Death Is Not (29 April-5 May). It includes several articles about the same topic: "How to have a better death (p. 9); End-of-life care. Mending mortality. Doctors are slowly realising that there is a better way to care for the dying." (pp. 4548); and "Death wishes. Living as long as posible is not people's main concern. 2017. p. 48.

73. Elias, Norbert. La soledad de los moribundos. Mexico DF: Fondo de Cultura Económica; 2010

74. de Saint-Exupéry, Antonie Le petit prince.

75. Delibes, Miguel. Cinco horas con Mario. Barcelona: Destino; 1969; p. 296. 
76. Jovell, Albert J. Cáncer: Biografía de un supervivencia. El espernzador testimonio de un médeico enfermo de cáncer. Barcelona: Planeta; 2008; p. 322 .

77. Albom M. Tusdays with Morris. New York: Doubleday; 1977.

78. Bayés, Ramón. Aprender a investigar, aprender a cuidar: Una guía para estudiantes y profesionales de la salud. Barcelona: Plataforma Editorial; 2012. p. 229.

79. Beauvoir, Simone de. La ceremonia del adiós. Barcelona: Edhasa; 1983.

\section{Annex}

I have worked with the library of the Medical School of the University of Barcelona (at the Casanova Street building, floors $7^{\text {th }}$, $6^{\text {th }}$, and 5th). It is useful to record here the library localization of the basic subjects for the research. Anybody can check quickly about the textbooks for each section. Textbooks or books recommended by the present teachers of the 44 courses of the Medical Doctor degree have a special green band in the book. When there are several editions - and that occurs often- the green band is kept only in the last three editions, even the previous editions are in the same stacks. Usually when there is a textbook in English and its Spanish translation both have the green band. All the books with a green band formed previously a special Library for the Students. But both types of books (recommended and not-recommended) are now together. That makes my research more complex, but apparently is better for medical students. It expands the space of the stacks, and there are more seats available for students. Here the number before the topic is the area of the library when those books can be located. This is essential to find a book that could present information about death and dying.

\section{First year}

Introduction to health (dispersed \& History of Medicine).

A2 Biostatistics.

B17 Epidemiology.

A1 Introduction to research.

A3 Anthropology.

A9 Demography.

Second year

A1 Psychology.
Third year

C30 Surgery.

C32 Anesthesiology.

B17 Reanimation.

B20 Diagnosis (anamnesis and exploration).

A11 Ethics (Medical ethics)

\section{Fourth year}

C28 Psychiatry.

\section{Fifth year}

A11 Legal Medicine.

A8 Occupational Medicine.

A14 Toxicology.

A12 Preventive Medicine.

A9-10 Public health.

A2 Statistics.

B16 Oncology.

A14 Radiotherapy.

Sixth year

C36 Obstetrics and gynecology.

B18-19 Pediatrics.

B19 Gerontology/Geriatrics.

A10 Hospitals.

B21 Palliative Medicine.

B16 Pain.

A11 Family Medicine.

A10 Primary care.

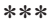

(JMDM, June 2017) 